\title{
El origen común de las instituciones de asistencia médica colectiva en Argentina y Uruguay: organización actual a ambos lados del rìo
}

rdai.com.br/index.php/rdai/article/view/421

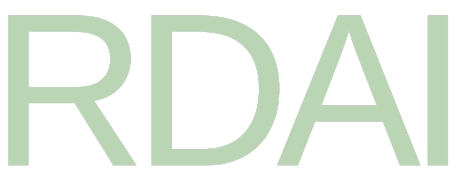

\section{Autores}

Natalia Veloso Giribaldi Universidad de Montevideo (Montevidéu, Uruguai)

DOI:

https://doi.org/10.48143/rdai.19.nvg

\section{Palavras-chave:}

Asistencia médica, Comparativo, Uruguay, Argentina

\section{Resumo}

El presente trabajo analiza los orígenes de la organización colectiva de la atención de la salud en Argentina y Uruguay, así como su configuración actual. En este sentido, identifica puntos de origen comunes para concluir que, en relación con el estado actual, estos sistemas comparten características comunes, ya que abarcan un sector importante de la población y estaban abiertos al público en general, independientemente de si pertenecen al respectivo campo de actividad o al fundador de la comunidad. Sin embargo, se diferencian por el hecho de que, si bien en Uruguay hubo adhesión de órganos originarios al Sistema Nacional Integrado de Salud, en Argentina el funcionamiento de Obras Sociales parece quedarse en la lógica de subsistemas o compartimentos estancos, advirtiendo de mayores desigualdades entre los diferentes subsectores.

\section{Biografia do Autor}

\section{Natalia Veloso Giribaldi, Universidad de Montevideo (Montevidéu, Uruguai)}

Profesora Titular de Derecho Público en el Posgrado de Gestión Financiera de Empresas Públicas en la Universidad de la República, Profesora Titular de Derecho Administrativo Sancionatorio en el Máster de Derecho Administrativo Económico de la Universidad de Montevideo, Doctora en Derecho por la Universidad de Montevideo (2005), Máster en Derecho Administrativo Económico por la Universidad de Montevideo (2011), Diplomada 
en Docencia Universitaria (2012), Profesora Agregada de Derecho Administrativo en la Universidad de Montevideo, Profesora de Derecho Público en la Facultad de Humanidades de la Universidad de Montevideo. Integrante del Foro Iberoamericano de Derecho Administrativo (FIDA). Autora de varios libros y publicaciones sobre la materia en el Uruguay y en el extranjero.

0000-0002-5340-2906 | natalia.veloso@delpiazzo.com

\section{Referências}

GIRIBALDI, Natalia Veloso. El origen común de las instituciones de asistencia médica colectiva en Argentina y Uruguay: organización actual a ambos lados del río. Revista de Direito Administrativo e Infraestrutura, São Paulo, v. 5, n. 19, p. 327-335, out./dez. 2021. DOI: [https://doi.org/10.48143/rdai.19.nvg].

Carlos E. DELPIAZZO - "Derecho Administrativo Especial”, A.M.F., Montevideo, Tercera Edición, Volumen 2, p. 124 y ss.

Pablo MONJE-REYES - "Economía solidaria, cooperativismo y descentralización: la gestión social puesta en práctica”, en Cuadernos EBAPE.BR vol.9 no.3 Rio de Janeiro Sept. 2011, On-line versión ISSN 1679-3951.

Carlos E. DELPIAZZO - "Derecho Administrativo Especial”, A.M.F., Montevideo, Tercera Edición, Volumen 2, p. 124 y ss.

Santiago PÉREZ DEL CASTILLO - "Los cuidados de la Salud, ¿̇égimen privado o público?”, Revista de Derecho Laboral, Tomo XXXVIII, No 179, Julio-Septiembre 1995, pág. 575 y ss.

Oscar CETRÀNGOLO y Ariel GOLDSCMITH - “Obras sociales en Argentina. Origen y situación actual de un sistema altamente desigual”, cece, p. 5 .

Juan Carlos VERONELLI y Magalí VERONELLI - "Los orígenes institucionales de la Salud Pública en Argentina”, OPS, 2004, Volumen 2, p. 503 y 504.

José Aníbal CAGNONI y Héctor FRUGONE SCHIAVONE - "Regulación Jurídica de la Asistencia a la Salud Humana en el Uruguay” (C.E.N., Montevideo, 1973).

Oscar CETRÀNGOLO y Ariel GOLDSCMITH - “Obras sociales en Argentina. Origen y situación actual de un sistema altamente desigual”.

Viviana BONPLAND y Alberto BOZZOLO - "El sistema de Salud Argentino. Problemas y propuestas para su desarrollo integrado”.

Viviana BONPLAND y Alberto BOZZOLO - "El sistema de Salud Argentino. Problemas y propuestas para su desarrollo integrado”.

\section{Publicado}




\section{Como Citar}

GIRIBALDI, N. V. El origen común de las instituciones de asistencia médica colectiva en Argentina y Uruguay: organización actual a ambos lados del rìo : The common origin of collective medical assistance institutions in Argentina and Uruguay: current organization on both sides of the river. Revista de Direito Administrativo e Infraestrutura |

RDAI, São Paulo: Thomson Reuters - Livraria RT, v. 5, n. 19, p. 327-335, 2021. DOI: 10.48143/rdai.19.nvg. Disponível em:

https://rdai.com.br/index.php/rdai/article/view/421. Acesso em: 7 fev. 2022.

\section{Edição}

\section{V.5_n. 19_(2021).}

\section{Seção}

Doutrina Estrangeira

\section{Licença}

\section{(1) 90}

Este trabalho está licenciado sob uma licença Creative Commons Attribution-

NonCommercial-NoDerivatives 4.0 International License.

(CC BY-NC-ND)

Este é um resumo (e não um substituto) da licença

Regras para publicaçãão

Direitrizes Editoriais

Direitos e Deveres

Errata e Retratação

Preservaçãa e Plagiarismo

Revisão e Avaliaçãa 
